\title{
Manajemen Asuhan Keperawatan Pada Ny. A Dengan Kecemasan Pada Penderita Diabetes Melitus Di Setia Luhur
}

\author{
Nazela Nanda Putri
}

\section{Nazelanandaputri261@gmail.com}

\section{BAB 1}

\section{PENDAHULUAN}

\subsection{Latar Belakang}

Diabetes melitus merupakan salah satu masalah kesehatan yang ada dilingkungan masyrakat dan masalah kesehatan kronik terjadi pada gangguan metabolik yang banyak terjadi dimasyarakat. Diabetes melitus merupakan suatu penyakit dimana terjadinya peningkatan kadar gula darah dalam tubuh, salah satu komplikasinya kaki kaki diabetik yang dapat mengakibatkan amputasi dan kematian (Yulia, 2020). Berdasarkan hasil riskesdes pada tahun 2018 angka terjadinya diabetes melitus pada usia >15 tahun keatas yakni dindonesia $(6,9 \%$.) Beberapa kota dengan presentasi cukup besar mempunyai penyakit diabetes melitus diantaranya: Aceh $(2,6 \%)$, Sumatera Barat $(1,8 \%)$, Sumatera utara $(2,3 \%)$.

Diabetes melitus mempunyai gejala yang mirip dan komplikasi pada tingkat lanjut. Bila seseorang terkena diabetes melitus tidak menerima perawatan secara rutin bisa menyebabkan beberapa komplikasi (Maruhashi \& Higashi, 2021). Kompikasi dalam diabetes melitus mempunyai jangka waktu yang lebih lama termasuk kardiovaskuler, kerusakan retina menyebabkan kebutaan dan kerusakaan saraf yang bisa menyebabkan impontensi dengan resiko amputasi, Sehingga dampak yang akan terjadi pada penderita diabetes melitus akan muncul kecemasan (Regina, Mu'ti \& Fitriany, 2021). 
Kecemasan merupakan respon tubuh terhadap peristiwa yang terjadi, dimana respons tubuh terhadap peristiwa yang terjadi, dimana respon tubuh tersebut lebih bersifat negatif sehingga menimbulkan ketidaknyamanan bagi klien (Zaini, 2019). Menurut DepKes RI, kecemasan adalah ketegangan, rasa tidak aman dan kekhawatiran yang timbul karena dirasakan terjadi sesuatu yang tidak menyenangkan tetapi sumbernya sebagian besar tidak diketahui dan berasal dari dalam (Wahyuni, 2018).

Kecemasan pada penderita diabetes melitus berpengaruh terhadaop fluktuasi glukosa darah yang menyebabkan kadar gula darah tidak stabil,meskipun telah diupayakan diet, latihan fisik maupun pemakaian obat secara tepat (Nurhayati,2018).Terapi mengatasi kecemasan seperti terapi hipnotis lima jari merupakan proses yang mengunakan kekuatan pikiran denganengrahkan tubuuntuk releksasi (Pardede,Simanjutak \& waruwu,2020). Berdasarkan uraian diatas maka penulis tertarik untuk mengambil kasus kecemasan pada diabetes melitus dengan judul Asuhan Keperawatan Pada Ny. A Dengan Kecemasan Pada Penderita Diabetes Melitus Di Setia Luhur Kec. Medan Helvetia. Pertimbangan utama pengambilan kasus ini pada Ny. A karena pada kehidupan sehari-hari memiliki kadar glukosa darah tinggi lebih cepat pada kondisi cemas akan memperburuk kondisi.

\subsection{Tujuan Penulisan}

\section{Tujuan umum}

Untuk memberikan asuhan keperawatan pada Ny. A dengan masalah kecemas

\section{Tujuan khusus}

a. Mahasiswa mampu melakukan pengkajian pada Ny. A dengan masalah kecemasan

b. Mahasiswa mampu melaksanakan diagnosa pada Ny. A dengan masalah kecemasan 
c. Mahasiswa mampu membuat intervensi pada Ny. A dengan masalah kecemasan

d. Mahasiswa mampu melakukan implementasi pada Ny. Adengan masalah kecemasan

e. Mahasiswa mampu membuat evaluasi pada Ny. A dengan masalah kecemasan 


\section{BAB 2}

\section{TINJAUAN TEORITIS}

\subsection{Konsep Kecemasan}

\subsubsection{Defenisi kecemasan}

Kecemasan merupakan suatu respon psikologis maupun fisiologis individu terhadap suatu keadaan yang tidak menyenangkan, atau reaksi atas situasi yang dianggap mengancam (Hulu \& Pardede, 2016). Kecemasan merupakan suatu keadaan perasaan gelisah, ketidaktentuan, ada rasa takut dari kenyataan atau persepsi ancaman sumber aktual yang tidak diketahui masalahnya (Pardede \& Simangunsong, 2020). Kecemasan adalah perasaan ketakutan yang tidak memiliki penyebab yang jelas dan tidak didukung oleh situasi,kecemasan dapat dirasakan oleh setiap orang jika mengalami tekanan dan perasaan yang mendalam menyebabkan masalah kejiwaan dan berkembangan dalam jangka panjang ( Pardede, Simanjuntak \& Manulu, 2020)

Kecemasan merupakan keadaan emosional yang mempunyai ciri keterangsangan fisiologis perasaan yang tidak menyenngkan dan perasaan aprhensi atau keadaan khawatir yang mengeluhkan bahwa sesuatu yang buruk akan terjadi dengan ditandai oleh afek negatif dan gejala ketegangan jasmani dalam mengantisipasi datangnya bahaya (Nevid et al, 2018). Kecemasan adalah perasaan was-was, khawatir, takut yang tidak jelas atau tidak nyaman seakan-akan terjadi sesuatu yang mengancam. Kecemasan adalah perasaan tidak nyaman atau khawatir yang samar disertai otonom (sumber seringkali tidak spesifik atau tidak diketahui individu) ; perasaan takut yang disebabkan oleh antisipasi terhadap bahaya. Hal ini merupakan isyarat kewaspadaan yang memperingatkan individu akan adanya bahaya dan memampukan individu untuk bertindak menghadapi ancaman 
(NANDA, 2018). Kecemasan suatu kondisi perasaan yang berkaitan dengan ketakutan disertai gejala fisik seperti jantung berdebar nafas pendek atau nyeri dada, keringat dingin tangan geetaran yang dapat disebabkan oleh genetik, biokimia otak dan mekanisme fight-fight.( Febrianti, Hamid, \& Wardani, 2015).

Kecemasan mungkin hadir pada beberapa tingkat dalam kehidupan setiap individu, tetapi derajat dan frekuensi dengan yang memanifestasikan berbeda secara luas. Respon masing-masing individu memiliki kecemasan berbeda. Tepi emosional yang memprovokasi kecemasan untuk merangsang kreativitas atau kemampuan pemecahan masalah, yang lainnya dapat menjadi bergerak ke tingkat patologis. Perasaan umumnya dikategorikan menjadi empat tingkat untuk tujuan pengobatan : ringan, sedang, berat, dan panik. Perawat dapat menemukan klien cemas di mana saja di rumah sakit atau lingkup masyarakat.

\subsubsection{Etiologi kecemasan}

\section{Faktor predisposisi}

Stressor predisposisi adalah semua ketegangan dalam kehidupan yang dapat menyebabkan timbulnya kecemasan (Stuart, Keliat \& Pasaribu, 2016). Ketegangan dalam kehidupan tersebut dapat berupa

a. Peristiwa Traumatik, yang dapat memicu terjadinya kecemasan berkaitan dengan krisis yang dialami individu baik krisis perkembangan atau situasional.

b. Konflik Emosional, yang dialami individu dan tidak terselesaikan dengan baik. Konflik antara id dan superego atau antara keinginan dan kenyataan dapat menimbulkan kecemasan pada individu.

c. Konsep diri terganggu akan menimbulkan ketidakmampuan individu berpikir secara realitas sehingga akan menimbulkan kecemasan. 
d. Frustasi akan menimbulkan rasa ketidakberdayaan untuk mengambil keputusan yang berdampak terhadap ego.

e. Gangguan fisik akan menimbulkan kecemasan karena merupakan ancaman terhadap integritas fisik yang dapat mempengaruhi konsep diri individu.

f. Pola mekanisme koping keluarga atau pola keluarga menangani stress akan mempengaruhi individu dalam berespon terhadap konflik yang dialami karena pola mekanisme koping individu banyak dipelajari dalam keluarga.

g. Riwayat gangguan kecemasan dalam keluarga akan mempengaruhi respons individu dalam berespons terhadap konflik dan mengatasi kecemasannya.

h. Medikasi yang dapat memicu terjadinya kecemasan adalah pengobatan yang mengandung benzodiazepin, karena benzodiazepine dapat menekan neurotransmiter gamma amino butyric acid (GABA) yang mengontrol aktivitas neuron di otak yang bertanggung jawab menghasilkan kecemasan.

\section{Faktor presipitasi}

Stresor presipitasi adalah semua ketegangan dalam kehidupan yang dapat mencetuskan timbulnya kecemasan (Stuart, Keliat \& Pasaribu, 2016). Stressor presipitasi kecemasan dikelompokkan menjadi dua bagian, yaitu :

a. Ancaman terhadap integritas fisik. Ketegangan yang mengancam integritas fisik yang meliputi :

1) Sumber Internal, meliputi kegagalan mekanisme fisiologis sistem imun, regulasi suhu tubuh, perubahan biologis normal (misalnya : hamil).

2) Sumber Eksternal, meliputi paparan terhadap infeksi virus dan bakteri, polutan lingkungan, kecelakaan, kekurangan nutrisi, tidak adekuatnya tempat tinggal.

b. Ancaman terhadap harga diri meliputi sumber internal dan eksternal : 
1) Sumber Internal : kesulitan dalam berhubungan interpersonal di rumah dan tempat kerja, penyesuaian terhadap peran baru. Berbagai ancaman terhadap integritas fisik juga dapat mengancam harga diri.

2) Sumber Eksternal : kehilangan orang yang dicintai, perceraian, perubahan status pekerjaan, tekanan kelompok, sosial budaya.

\subsubsection{Rentang respon}

Menurut Stuart (2006) "menjelaskan rentang respon individu terhadap cemas berfluktuasi antara respon adaptif dan maladaptif. Rentang respon yang paling adaptif adalah antisipasi dimana individu siap siaga untuk beradaptasi dengan cemas yang mungkin muncul. Sedangkan rentang yang paling maladaptif adalah panik dimana individu sudah tidak mampu lagi berespon terhadap cemas yang dihadapi sehingga mengalami ganguan fisik, perilaku maupun kognitif. Seseorang berespon adaptif terhadap kecemasannya maka tingkat kecemasan yang dialaminya ringan, semakin maladaptif respon seseorang terhadap kecemasan maka semakin berat pula tingkat kecemasan yang dialaminya, seperti gambar dibawah ini :"

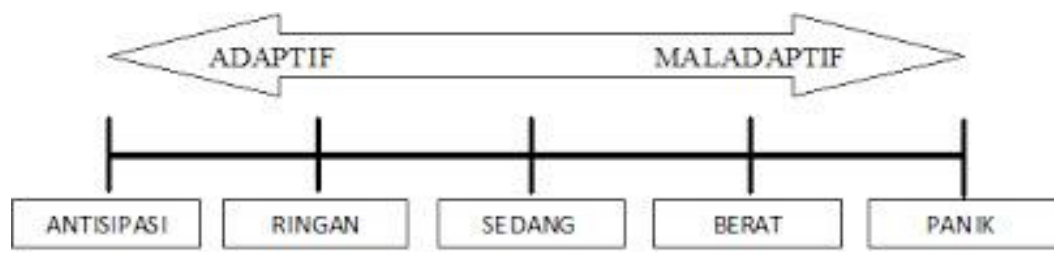

Gambar Rentang Respon Kecemasan (Stuart,2006)

\subsubsection{Tanda dan Gejala Kecemasan}

Menurut Utami, Astuti\& Livana (2017) tanda dan gejala kecemasan adalah :

\section{Respons fisik :}


a. Kardiovaskular : Palpitasi, Jantung Bedebar, Tekanan Darah Meninggi, Denyut Nadi Cepat

b. Pernafasan : Napas Cepat, Napas Pendek, Tekanan Pada Dada, Napas Dangkal, Pembengkakan Pada Tenggorokan, TerengahEngah

c. Neuromuskular : Refleks Meningkat, Insomnia, Tremor, Gelisah, Wajah Tegang, Kelemahan Umum, Kaki Goyah, Gerakan Yang Janggal

d. Gastrointestinal : Anoreksia, Diare/Konstipasi, Mual, Rasa Tidak Nyaman Pada Abdomen

e. Traktur Urinarius : Sering Berkemih Dan Tidak Dapat Menahan Kencing

f. Kulit : Wajah Kemerahan, Berkeringat, Gatal, Rasa Panas Pada Kulit

\section{Respons Kognitif :}

Lapang persepsi menyempit, tidak mampu menerima rangsang luar, berfokus pada apa yang menjadi perhatiannya

\section{Respons Perilaku :}

Gerakan tersentak-sentak, bicara berlebihan dan cepat, perasaan tidak aman,

\section{Respons Emosi :}

Menyesal, iritabel, kesedihan mendalam, takut, gugup, sukacita berlebihan, ketidakberdayaan meningkat secara menetap, ketidakpastian, kekhawatiran meningkat, fokus pada diri sendiri, perasaan tidak adekuat, ketakutan, distressed, perihatin.

\subsubsection{Penatalaksanaan Kecemasan}

Menurut Hawari (2008) penatalaksanaan ansietas pada tahap pencegahaan dan terapi memerlukan suatu metode pendekatan yang bersifat holistik, yaitu mencangkup fisik (somatik), psikologik atau psikiatrik, psikososial dan psikoreligius. Selengkpanya seperti pada uraian berikut : 
1. Upaya meningkatkan kekebalan terhadap stress, dengan cara :

a. Makan makanan yang berigizi dan seimbang

b. Tidur yang cukup

c. Olahraga yang teratur

d. Tidak merokok dan tidak minum minuman keras

2. Terapi Psikofarmaka

Terapi psikofarmaka yang sering dipakai adalah obat anti cemas (anxiolytic), yaitu seperti diazepam, clobazam, bromazepam, lorazepam, buspirone $\mathrm{HCl}$, meprobamate dan alprazolam.

3. Terapi Somatik

Gejala atau keluhan fisik (somatik) sering dijumpai sebagai gejala ikutan atau akibat dari kecemasan yang bekerpanjangan. Untuk menghilangkan keluhan-keluhan somatik (fisik) itu dapat diberikan obat-obatan yang ditujukan pada organ tubuh yang bersangkutan.

4. Psikoterapi

Psikoterapi diberikan tergantung dari kebutuhan individu, antara lain

a. Psikoterapi Suportif

b. Psikoterapi Re-Edukatif

c. Psikoterapi Re-Konstruktif

d. Psikoterapi Kognitif

e. Psikoterapi Psikodinamik

f. Psikoterapi Keluarga

5. Terapi Psikoreligius

Untuk meningkatkan keimanan seseorang yang erat hubungannya dengan kekebalan dan daya tahan dalam menghadapi berbagai problem kehidupan yang merupakan stressor psikososial.

\subsection{Konsep Asuhan Keperawatan}

\subsubsection{Pengkajian}




\section{Faktor Predisposisi}

Berbagai teori telah dikembangkan untuk menjelaskan asal ansietas (Waryuningsih,2021) :

\section{a. Teori Psikoanalitik}

Ansietas adalah konflik emosional yang terjadi antara dua elemen kepribadian, ID dan superego. ID mewakili dorongan insting dan impuls primitif seseorang, sedangkan superego mencerminkan hati nurani seseorang dan dikendalikan oleh norma- norma budaya seseorang. Ego atau Aku, berfungsi menengahi hambatan dari dua elemen yang bertentangan dan fungsi ansietas adalah mengingatkan ego bahwa ada bahaya

\section{b. Teori Interpersonal}

Ansietas timbul dari perasaan takut terhadap tidak adanya penerimaan dari hubungan interpersonal. Ansietas juga berhubungan dengan perkembangan, trauma seperti perpisahan dan kehilangan sehingga menimbulkan kelemahan spesifik.Orang dengan harga diri rendah mudah mengalami perkembangan ansietas yang berat.

\section{c. Teori Perilaku}

Ansietas merupakan produk frustasi yaitu segala sesuatu yang mengganggu kemampuan seseorang untuk mencapai tujuan yang diinginkan.Daftar tentang pembelajaran meyakini bahwa individu yang terbiasa dalam kehidupan dininya dihadapkan pada ketakutan yng berlebihan lebih sering menunjukkan ansietas pada kehidupan selanjutnya.

\section{d. Kajian Keluarga}

Menunjukkan bahwa gangguan ansietas merupakan hal yang biasa ditemui dalam suatu keluarga.Ada tumpang tindih dalam gangguan ansietas dan antara gangguan ansietas dengan depresi.

\section{e. Kajian Biologis}

Menunjukkan bahwa otak mengandung reseptor khusus benzodiazepine. Reseptor ini mungkin membantu mengatur 
ansietas penghambat dalam aminobutirik. Gamma neuroregulator (GABA) juga mungkin memainkan peran utama dalam mekanisme biologis berhubungan dengan ansietas sebagaimana halnya endorfin. Selain itu telah dibuktikan kesehatan umum seseorang mempunyai akibat nyata sebagai predisposisi terhadap ansietas. Ansietas mungkin disertai dengan gangguan fisik dan selanjutnya menurunkan kapasitas seseorang untuk mengatasi stressor.

\section{Faktor Presipitasi}

Stressor pencetus mungkin berasal dari sumber internal atau eksternal. Stressor pencetus dapat dikelompokkan menjadi 2 kategori (Pratiwi, Widianti \& Solehati, 2017):

a. Ancaman terhadap integritas seseorang meliputi ketidakmampuan fisiologis yang akan datang atau menurunnya kapasitas untuk melakukan aktifitas hidup sehari- hari.

b. Ancaman terhadap sistem diri seseorang dapat membahayakan identitas, harga diri dan fungsi sosial yang terintegrasi seseorang.

\section{Perilaku}

Kecemasan dapat diekspresikan secara langsung melalui perubahan fisiologi dan perilaku dan secara tidak langsung melalui timbulnya gejala atau mekanisme koping dalam upaya melawan kecemasan. Intensitas perilaku akan meningkat sejalan dengan peningkatan tingkat kecemasan.

a. Respon Fisiologis Terhadap Ansietas

\begin{tabular}{|l|l|}
\hline Sistem Tubuh & \multicolumn{2}{|c|}{ Respons } \\
\hline Kardiovaskuler & • Palpitasi. \\
& - Jantung berdebar. \\
& - Tekanan darah meningkat dan denyut nadi menurun. \\
& - Rasa mau pingsan dan pada akhirnya pingsan. \\
\hline
\end{tabular}




\begin{tabular}{|c|c|}
\hline Pernafasan & $\begin{array}{l}\text { - } \\
\text { - } \text { Pernapasan dangkal. } \\
\text { - } \text { Rasa tertekan pada dada. } \\
\text { - Pembengkakan pada tenggorokan. } \\
\text { - } \text { Rasa tercekik. } \\
\text { - } \text { Terengah-engah. }\end{array}$ \\
\hline Neuromuskular & $\begin{array}{l}\text { - } \text { Peningkatan reflek. } \\
\text { - } \text { Reaksi kejutan. } \\
\text { - } \text { Insomnia. } \\
\text { - Ketakutan. } \\
\text { - Gelisah. } \\
\text { - } \text { Wajah tegang. } \\
\text { - Kelemahan secara umum. } \\
\text { - Gerakan lambat. } \\
\text { - Gerakan yang janggal. }\end{array}$ \\
\hline Gastrointestinal & $\begin{array}{l}\text { - } \text { Kehilangan nafsu makan. } \\
\text { - } \text { Menolak makan. } \\
\text { - } \text { Perasaan dangkal. } \\
\text { - Rasa tidak nyaman pada abdominal. } \\
\text { - Rasa terbakar pada jantung. } \\
\text { - Nausea. } \\
\text { - } \text { Diare. }\end{array}$ \\
\hline Perkemihan & $\begin{array}{l}\text { - } \quad \text { Tidak dapat menahan kencing. } \\
\text { - } \quad \text { Sering kencing. }\end{array}$ \\
\hline Kulit & $\begin{array}{l}\text { - } \text { Rasa terbakar pada mukosa. } \\
\text { - } \text { Berkeringat banyak pada telapak tangan. } \\
\text { - } \text { Gatal-gatal. } \\
\text { - } \quad \text { Perasaan panas atau dingin pada kulit. }\end{array}$ \\
\hline
\end{tabular}


- Muka pucat dan bekeringat diseluruh tubuh.

b. Respon Perilaku Kognitif

\begin{tabular}{|c|c|}
\hline Sistem & Respons \\
\hline Perilaku & $\begin{array}{l}\text { - } \text { Gelisah. } \\
\text { - } \text { Ketegangan fisik. } \\
\text { - } \text { Tremor. } \\
\text { - } \text { Gugup. } \\
\text { - } \text { Bicara cepat. } \\
\text { - Tidak ada koordinasi. } \\
\text { - Kecenderungan untuk celaka. } \\
\text { - Menarik diri. } \\
\text { - Menghindar. } \\
\text { - Terhambat melakukan aktifitas. }\end{array}$ \\
\hline Kognitif & $\begin{array}{l}\text { - } \text { Gangguan perhatian. } \\
\text { - } \text { Konsentrasi hilang. } \\
\text { - } \quad \text { Pelupa. } \\
\text { - } \quad \text { Salah tafsir. } \\
\text { - } \text { Adanya bloking pada pikiran. } \\
\text { - } \quad \text { Menurunnya lahan persepsi. } \\
\text { - } \quad \text { Kreatif dan produktif menurun. } \\
\text { - } \quad \text { Bingung. }\end{array}$ \\
\hline & $\begin{array}{l}\text { - } \quad \text { Khawatir yang berlebihan. } \\
\text { - Hilang menilai objektifitas. } \\
\text { - } \quad \text { Takut akan kehilangan kendali. } \\
\text { - Takut yang berlebihan. }\end{array}$ \\
\hline Afektif & $\begin{array}{l}\text { - Mudah terganggu. } \\
\text { - Tidak sabar. }\end{array}$ \\
\hline
\end{tabular}




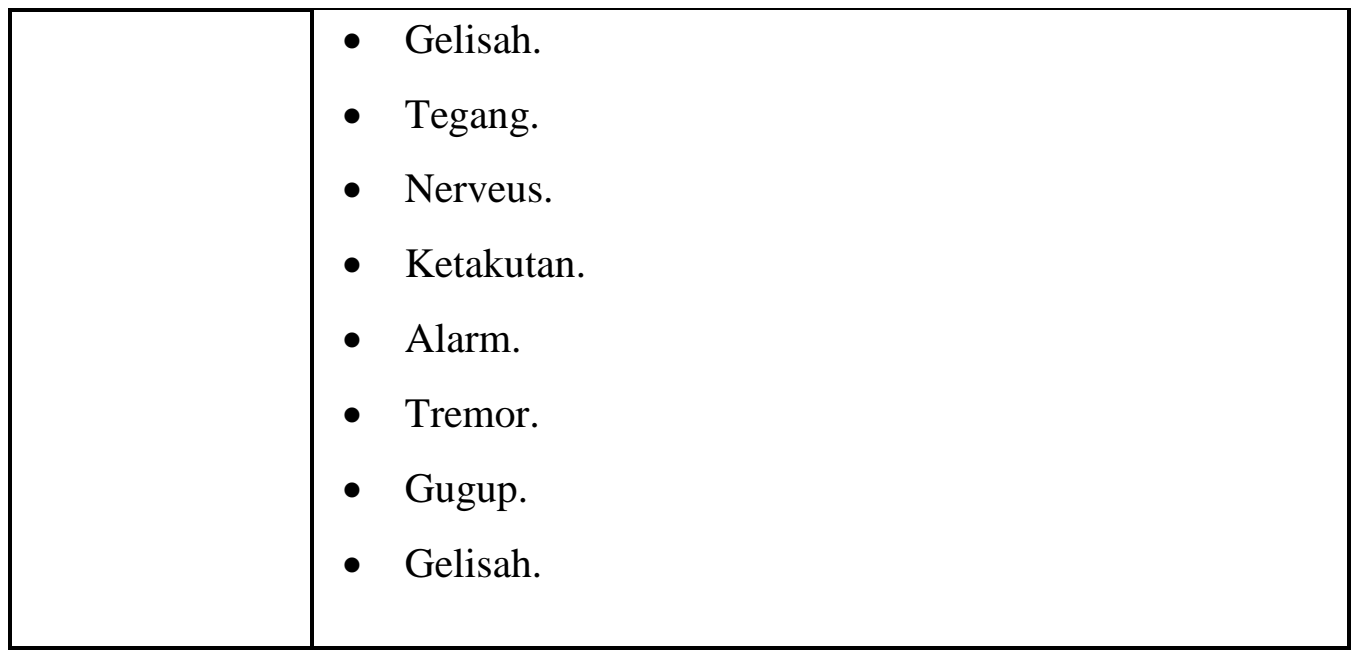

\section{Sumber Koping}

Individu dapat mengalami stress dan ansietas dengan menggerakkan sumber koping tersebut di lingkungan. Sumber koping tersebut sebagai modal ekonomok, kemampuan penyelesaian masalah, dukungan sosial dan keyakinan budaya dapat membantu seseorang mengintegrasikan pengalaman yang menimbulkan stress dan mengadopsi strategi koping yang berhasil ( Rahayu, 2016).

5. Mekanisme Koping

Ketika mengalami ansietas individu menggunakan berbagai mekanisme koping untuk mencoba mengatasinya dan ketidakmampuan mengatasi ansietas secara konstruktif merupakan penyebab utama terjadinya perilaku patologis. Ansietas tingkat ringan sering ditanggulangi tanpa yang serius.

Tingkat ansietas sedang dan berat menimbulkan 2 jenis mekanisme koping :

a. Reaksi yang berorientasi pada tugas, yaitu upaya yang disadari dan berorientasi pada tindakan untuk memenuhi secara realitis tuntutan situasi stress.

b. Mekanisme pertahanan ego, membantu mengatasi ansietas ringan dan sedang, tetapi jika berlangsung pada tingkat sadar dan melibatkan 
penipuan diri dan distorsi realitas, maka mekanisme ini dapat merupakan respon maladaptif terhadap stress.

\subsubsection{Diagnosa Keperawatan}

Adapun diagnosa yang biasanya muncul adalah :

1. Koping Individu Tidak Efektif

2. Kecemasan

3. Ketidakberdayaan

4. Isolasi Sosial

5. Perubahan Proses Berfikir

\subsubsection{Intervensi Keperawatan}

\section{Kecemasan}

Tujuan :

- Klien mampu mengenal pengertian penyebab tanda gejala dan akibat

- Klien mampu mengetahui cara mengatasi ansietas

- Klien mampu mengatasi ansietas dengan melakukan latihan relaksasi tarik nafas dalam

- Klien mampu mengatasi ansietas dengan melakukan latihan distraksi

- Klien mampu mengatasi ansietas dengan melakukan hipnotis lima jari

- Klien mampu merasakan manfaat dari latihan yang dilakukan

- Klien mampu membedakan perasaan sebelum dan sesudah latihan

Tindakan :

a. Kaji tanda dan gejala ansietas dan kemampuan klien mengurangi kecemasan

b. Jelaskan tanda dan gejala, penyebab dan akibat dari kecemasan

c. Latihan cara mengatasi kecemasan : 
1) Teknik relaksasi napas dalam

2) Distraksi : bercakap-cakap hal positif

3) Hipnotis 5 jari fokus padahal-hal yang positif

d. Bantu klien melakukan latihan sesuai dengan jadwal kegiatan.

\section{Koping tidak efektif}

Tujuan :

- Klien mampu mengetahui perubahan kondisi kesehatan dan kemampuannya mengatasi perubahan

- Klien mampu mengetahui pengertian tanda dan gejala penyebab serta akibat dari ketidakefektifan koping

- Klien mampu mengetahui cara mengatasi ketidakefektifan koping

- Klien mampu mengatasi masalah secara bertahap

- Klien mampu menggunakan sumber/daya sistem pendukung dalam mengatasi masalah

- Klien mampu merasakan manfaat latihan yang dilakukan

- Klien mampu mengembangkan koping yang efektif klien mampu merasakan manfaat sistem pendukung

Tindakan :

a. Kaji tanda dan gejala ketidakefektifan koping

b. Jelaskan proses terjadinya ketidakefektifan koping

c. Diskusikan koping (upaya atau cara) mengatasi masalah pada masa lalu

d. Koping (upaya) yang berhasil dan tidak berhasil. Berikan pujian

e. Pemanfaatan sumber daya atau sistem pendukung dalam mengatasi masalah

f. Latihan menggunakan upaya menyelesaikan masalah saat ini dengan menggunakan cara lama yang berhasil atau cara baru.

- Buat daftar masalah yang dihadapi

- Buat daftar cara (lama dan baru) yang akan digunakan

- Pilih, latih, dan jadwalkan cara yang akan digunakan untuk masalah yang dihadapi 
- Evaluasi hasil jika berhasil dibudidayakan jika kurang berhasil dipilih cara lain pada daftar cara nomor kedua

g. Latih menggunakan sistem pendukung yang teratur

h. Beri motivasi dan pujian atas keberhasilan klien mengatasi masalah

\section{Gangguan citra tubuh}

Tujuan :

- Klien mampu mengenal bagian tubuh yang sehat dan yang terganggu atau sakit

- Klien mampu mengetahui cara mengatasi gangguan citra tubuh

- Klien mampu mengafirmasi bagian tubuh yang sehat

- Klien mampu melatih dan menggunakan bagian tubuh yang sehat

- Klien mampu merawat dan melatih bagian tubuh yang terganggu

- Klien mampu mengevaluasi manfaat yang telah dirasakan dari bagian tubuh yang terganggu

- Klien mampu mengevaluasi manfaat bagian tubuh yang masih sehat

- Klien mampu merasakan manfaat latihan pada bagian tubuh yang terganggu

Tindakan :

a. Kaji tanda dan gejala gangguan citra tubuh dan kemampuan klien mengatasinya.

b. Jelaskan tanda dan gejala, penyebab dan akibat gangguan citra tubuh

c. Diskusikan persepsi, perasaan, dan harapan klien terhadap citra tubuhnya

d. Menjelaskan perubahan-perubahan fisik yang terjadi pada ibu hamil

e. Motivasi klien untuk merawat dan meningkatkan citra tubuh seperti : menggunakan make up dan skincare untuk wajah yang berjerawat. 
f. Motivasi klien untuk melakukan latihan meningkatkan citra tubuh sesuai jadwal dan beri pujian. 


\section{BAB 3}

\section{TINJAUN KASUS}

\subsection{Pengkajian Keperawatan}

\section{Nama : Ny .A}

Usia : 36 tahun

Tahun no reg :-

Ruangan : -

Tgl masuk rs: -

Tgl pengkajian : 6 oktober 2021

Alamat : Jalan setia luhur kec

medan helvetia
Kondisi saat MRS: lemas,kesemutan, gatal, gemetaran pusing luka

yang lama sembuh, Kadar glukosa darah tinggi

\section{Kondisi saat ini :}

Ny. A mengeluh badannya terasa lemas,kesemutan, gatal, gemetaran pusing dan luka yang lama sembuh, sehingga Ny.A tidak mampu melakukan aktivitas seperti biasanya, hingga membuat Ny. A takut dan gelisah dan tidak dapat melakukan aktifitasnya 
3.1.1 Faktor Predisposisi Dan Faktor Presipitasi

\begin{tabular}{|c|c|c|c|c|}
\hline \multirow[t]{2}{*}{ Faktor predisposisi } & \multicolumn{3}{|l|}{ Faktor presipitasi } & \multirow[t]{2}{*}{ STRESSOR } \\
\hline & Nature & Origin & $\begin{array}{l}\text { Number \& } \\
\text { Timing }\end{array}$ & \\
\hline $\begin{array}{l}\text { Biologis: } \\
\begin{array}{l}\text { 1. Diabetes melitus } \\
\text { 2. Ny. A menderita diabetes menderita diabetes melitus } \\
3 \text { tahun yang lalu } \\
\text { 3. Ny. A sering mengkonsumsi makanan manis } \\
\text { 4. Ny. A tidak rutin check up kepelayanan kesehatan }\end{array}\end{array}$ & 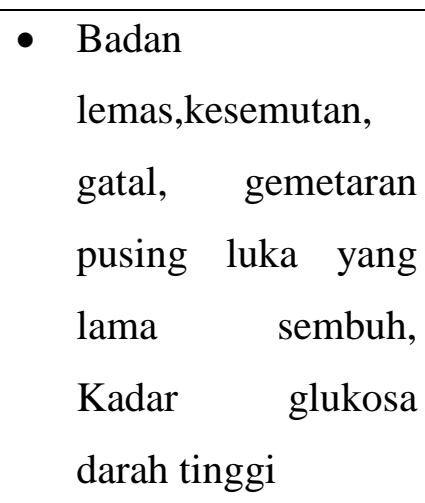 & Internal & $\begin{array}{l}\text { Sejak } 2 \\
\text { minggu yang } \\
\text { lalu }\end{array}$ & - Diabetes melitus \\
\hline Psikologis : & - Cemas,Takut, & Internal & Sejak & - Cemas, \\
\hline
\end{tabular}




\begin{tabular}{|c|c|c|c|c|}
\hline $\begin{array}{l}\text { 1. Ny. A memiliki kepribadian yang terbuka setiap ada } \\
\text { masalah akan dibicarakan dengan suaminya } \\
\text { 2. Ny. A merasa gemetaran ,luka lama sembuh dan } \\
\text { juntung berdebar kencang } \\
\text { 3. Ny. A merasa cemas, takut gelisah dan panikan jika } \\
\text { memikirkan penyakitnya }\end{array}$ & $\begin{array}{l}\text { gelisah,jantung } \\
\text { berdebar,gemetran } \\
\text { - Sering kepikiran } \\
\text { penyakitnya }\end{array}$ & & $\begin{array}{l}\text { minggu yang } \\
\text { lalu }\end{array}$ & panikan, kwatir \\
\hline $\begin{array}{l}\text { Sosiocultural : } \\
\text { 1. Ny. A seorang perempuan umur } 36 \text { tahun } \\
\text { 2. Ny. A menikah dan memiliki } 2 \text { orang anak } \\
\text { 3. Ny.A merupakan ibu rumah tangga } \\
\text { 4. Sebelumnya Ny.A aktif terlibat dalam kegiatan } \\
\text { dilingkungan tempat tinggal seperti perwiritan atau } \\
\text { pengajian } \\
\text { 5. Ny.A merupakan orang jawa dan menurut Ny.A tidak } \\
\text { ada kebiasaan yang bertentangan dengan kesehatan } \\
\text { 6. Ny.A beragama islam dan taat menjalankan ibadah } \\
\text { 7. Ny.A jarang check up penyakitnya }\end{array}$ & \begin{tabular}{|lr} 
- & \multicolumn{2}{c}{ Cemas karena tidak } \\
bisa & bersosial \\
mengikuti kegiatan & kn \\
lingkungan & tempat \\
tinggalnya &
\end{tabular} & Eksternal & $\begin{array}{lr}\text { Sejak } & 2 \\
\text { minggu } & \text { yang } \\
\text { lalu } & \end{array}$ & Cemas \\
\hline \multicolumn{5}{|l|}{ GENOGRAM } \\
\hline
\end{tabular}




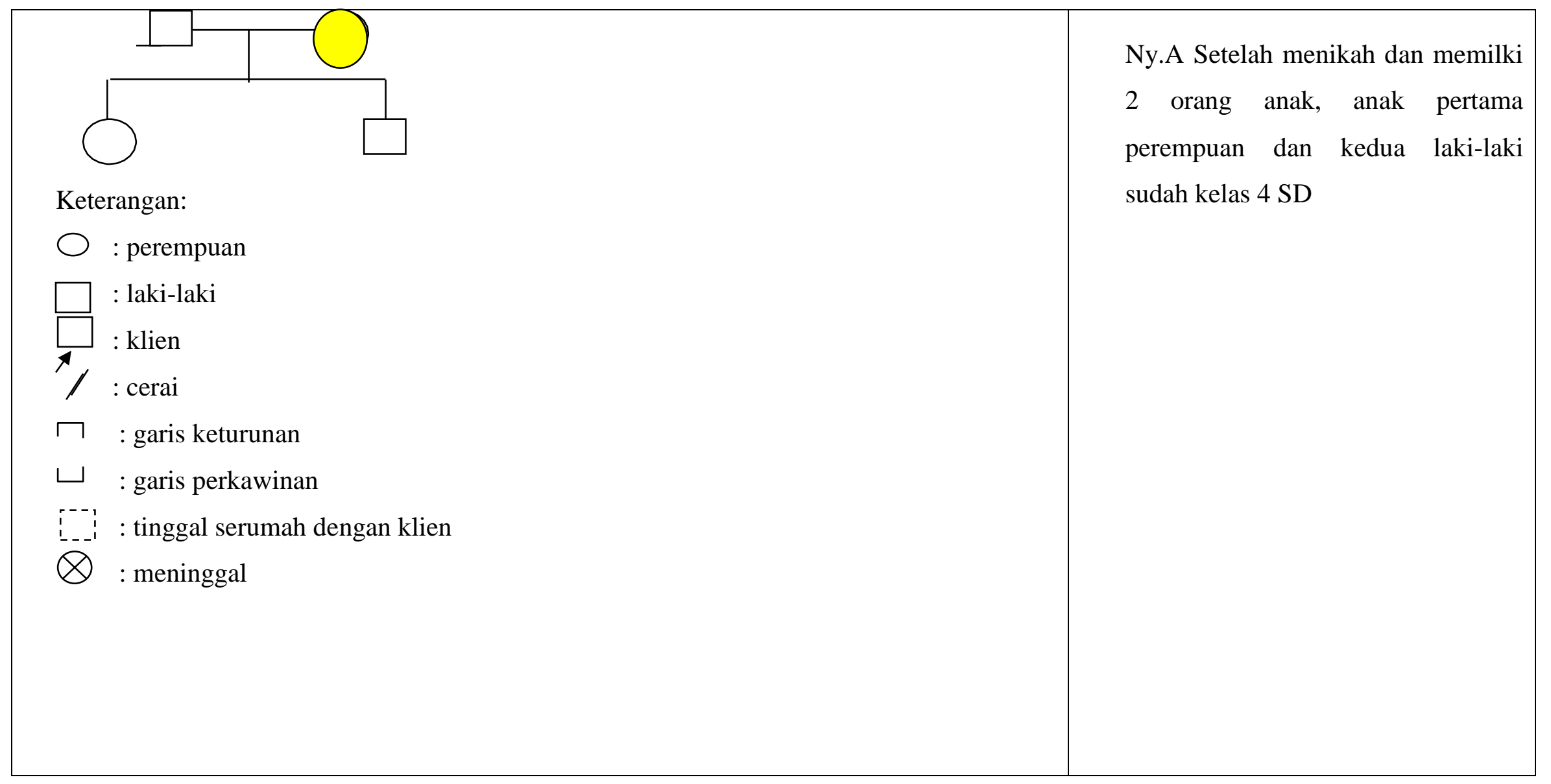


3.1.2 Penilaian (Respon)Terhadap Stressor

\begin{tabular}{|c|c|c|c|c|c|c|}
\hline STRESSOR & KOGNITIF & AFEKTIF & FISIOLOGIS & PERILAKU & SOSIAL & $\begin{array}{l}\text { DIAGNOSA } \\
\text { KEPERAWATAN }\end{array}$ \\
\hline $\begin{array}{l}\text { BIOLOGIS } \\
\text { - (Diabetes } \\
\text { melitus) }\end{array}$ & $\begin{array}{l}\text { - } \text { Menurut Ny.A } \\
\text { penyakit } \\
\text { Diabetes melitus } \\
\text { diakibatkan } \\
\text { karena } \\
\text { pengkonsumsi } \\
\text { makanan manis } \\
\text { - Menganggap } \\
\text { penyakit yang } \\
\text { diderita serius } \\
\text { - Tidak tahu apa } \\
\text { yang harus } \\
\text { dilakukan untuk } \\
\text { penyakitnya }\end{array}$ & $\begin{array}{l}\text { - Ny.A merasa } \\
\text { sedih dan } \\
\text { bingung } \\
\text { dengan } \\
\text { kondisi } \\
\text { penyakitnya }\end{array}$ & 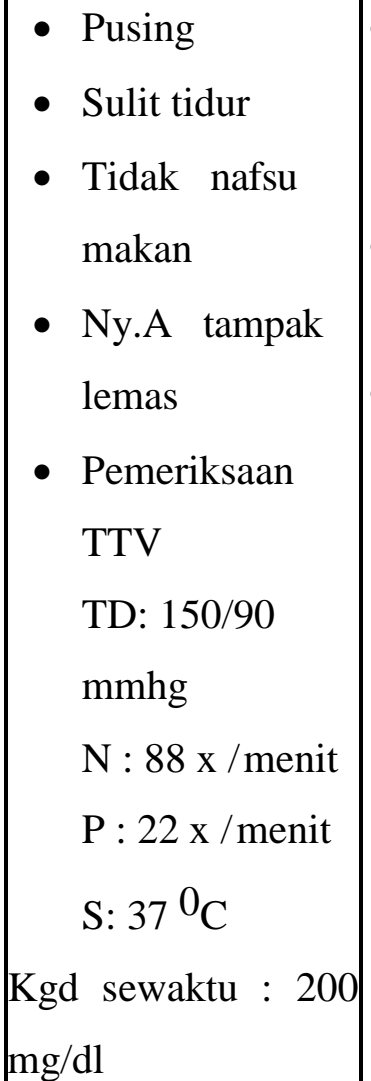 & $\begin{array}{l}\text { - } \\
\text { Ny.Sjarang } \\
\text { kontrol ke } \\
\text { rumah sakit } \\
\text { - } \text { Ekspresi } \\
\text { muka lesu } \\
\text { - Ny.Atampak } \\
\text { lemasdan } \\
\text { gemetaran }\end{array}$ & $\begin{array}{l}\text { - Pasien } \\
\text { mendatangi } \\
\text { dan } \\
\text { menggunakan } \\
\text { fasilitas } \\
\text { kesehatan yang } \\
\text { ada untuk } \\
\text { mencari } \\
\text { kesembuhan } \\
\text { terhadap } \\
\text { masalah yang } \\
\text { dihadapi saat } \\
\text { ini }\end{array}$ & - Ansietas \\
\hline
\end{tabular}




\begin{tabular}{|c|c|c|c|c|c|c|}
\hline $\begin{array}{l}\text { PSIKOLOGIS } \\
\text { - sedih, cemas, } \\
\text { kesal dan } \\
\text { Bingung } \\
\text { dengan kondisi } \\
\text { penyakit dan } \\
\text { pengobata } \\
\text { n serta } \\
\text { Perawatannya }\end{array}$ & $\begin{array}{l}\text { - Ny.A tidak tahu } \\
\text { bahwa } \\
\text { badannya } \\
\text { menjadi lemah, } \\
\text { gemetaran dan } \\
\text { luka yang lama } \\
\text { sembuh } \\
\text { merupakan } \\
\text { dampak dari } \\
\text { penyakit yang } \\
\text { diderita } \\
\text { Ny.A mengaku } \\
\text { bosan di rumah } \\
\text { sakit } \\
\text { Ny.A tidak tahu } \\
\text { pengobatan } \\
\text { seperti apa lagi } \\
\text { yang dapat } \\
\text { dilakukan untuk }\end{array}$ & $\begin{array}{l}\text { - Merasa kesal } \\
\text { dengan } \\
\text { penyakitnya } \\
\text { yang tidak } \\
\text { sembuh- } \\
\text { sembuh }\end{array}$ & $\begin{array}{l}\text { - Pusing } \\
\text { - Mual } \\
\text { - Sulit tidur dan } \\
\text { sering } \\
\text { terbangun } \\
\text { apabila tidur } \\
\text { - Bahu terasa } \\
\text { tegang } \\
\text { - Tidak nafsu } \\
\text { makan } \\
\text { - Ny.A tampak } \\
\text { lemas } \\
\text { - Wajah Ny.A } \\
\text { tampak lemas } \\
\text { - Wajah Ny. A } \\
\text { tampak pucat } \\
\text { - Pemeriksaan } \\
\text { TTV }\end{array}$ & $\begin{array}{l}\text { - } \text { Tampak } \\
\text { cemas dan } \\
\text { tidak } \\
\text { tenang } \\
\text { - Kadang } \\
\text { Ny.S } \\
\text { tampak } \\
\text { murung } \\
\text { - Ny.S } \\
\text { tampak } \\
\text { gelisah } \\
\text { - Ny.Atampa } \\
\text { k pasif } \\
\text { dalam } \\
\text { menerima } \\
\text { perawatan } \\
\text { Ny.A } \\
\text { menunduk }\end{array}$ & $\begin{array}{l}\text { - Hubungan } \\
\text { Ny.Adengan } \\
\text { suami baik } \\
\text { - Ny.A kurang } \\
\text { bersosialisasi } \\
\text { dengan } \\
\text { keluarga } \\
\text { Ny.Atetap } \\
\text { mengikuti } \\
\text { program } \\
\text { pengobatan } \\
\text { yang } \\
\text { diberikan } \\
\text { kepadanya } \\
\text { akan tetapi } \\
\text { sikap Ny.A } \\
\text { pasif dalam } \\
\text { menerima } \\
\text { perawatan }\end{array}$ & $\begin{array}{l}\text { - Kurang } \\
\text { pengetahuan }\end{array}$ \\
\hline
\end{tabular}




\begin{tabular}{|c|c|c|c|c|c|c|}
\hline & $\begin{array}{l}\text { mengobati } \\
\text { penyakitnya }\end{array}$ & & $\begin{array}{l}\text { TD: } 150 / 90 \\
\text { mmhg } \\
\mathrm{N}: 88 \mathrm{x} / \text { menit } \\
\mathrm{P}: 20 \mathrm{x} / \text { menit } \\
\mathrm{S}: 36^{0} \mathrm{C} \\
\text { Kgd sewaktu } \\
200 \mathrm{mg} / \mathrm{dl}\end{array}$ & saat bercerita & & \\
\hline $\begin{array}{r}\text { SOSIAL } \\
\text { BUDAYA } \\
\text { • sering } \\
\text { Memikirkan } \\
\text { anak-anak } \\
\text { yang masih } \\
\text { Yang jauh } \\
\text { dari } \\
\text { rumah } \\
\text { merasa }\end{array}$ & $\begin{array}{l}\text { - } \text { Ny.A merasa } \\
\text { tidak berdaya } \\
\text { dengan } \\
\text { keadaannya } \\
\text { sejarang yang } \\
\text { tidak bisa bekerja } \\
\text { bingung } \\
\text { memikirkan } \\
\text { anak-anak yang } \\
\text { jauh merantau } \\
\text { menurut pasien, }\end{array}$ & $\begin{array}{l}\text { - } \text { Merasa } \\
\text { khawatir dan } \\
\text { sedih kepada } \\
\text { suami yang } \\
\text { merawatnya } \\
\text { setiap hari } \\
\text { - Merasa } \\
\text { bersalah } \\
\text { karena } \\
\text { merasa } \\
\text { merepotkan }\end{array}$ & $\begin{array}{l}\text { - } \text { Pusing } \\
\text { - Mual } \\
\text { - Mulut tampak } \\
\text { kering } \\
\text { - Sulit tidur } \\
\text { - Bahu terasa } \\
\text { - tegang } \\
\text { - Konstipasi } \\
\text { - Tidak nafsu } \\
\text { makan } \\
\text { - Ny.A tampak }\end{array}$ & $\begin{array}{l}\text { - Kontak mata } \\
\text { ada tapi tidak } \\
\text { bertahan } \\
\text { lama } \\
\text { - Volume } \\
\text { suara } \\
\text { mengecil } \\
\text { - Ny.S tampak } \\
\text { gelisah }\end{array}$ & 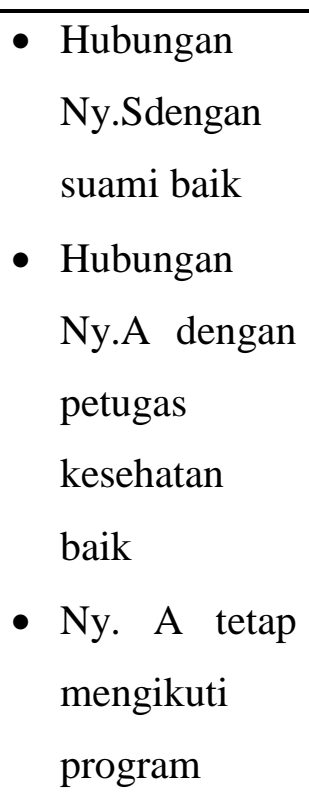 & $\begin{array}{ll}\text { - } & \text { Penampilan } \\
\text { peran tidak } \\
\text { efektif }\end{array}$ \\
\hline
\end{tabular}




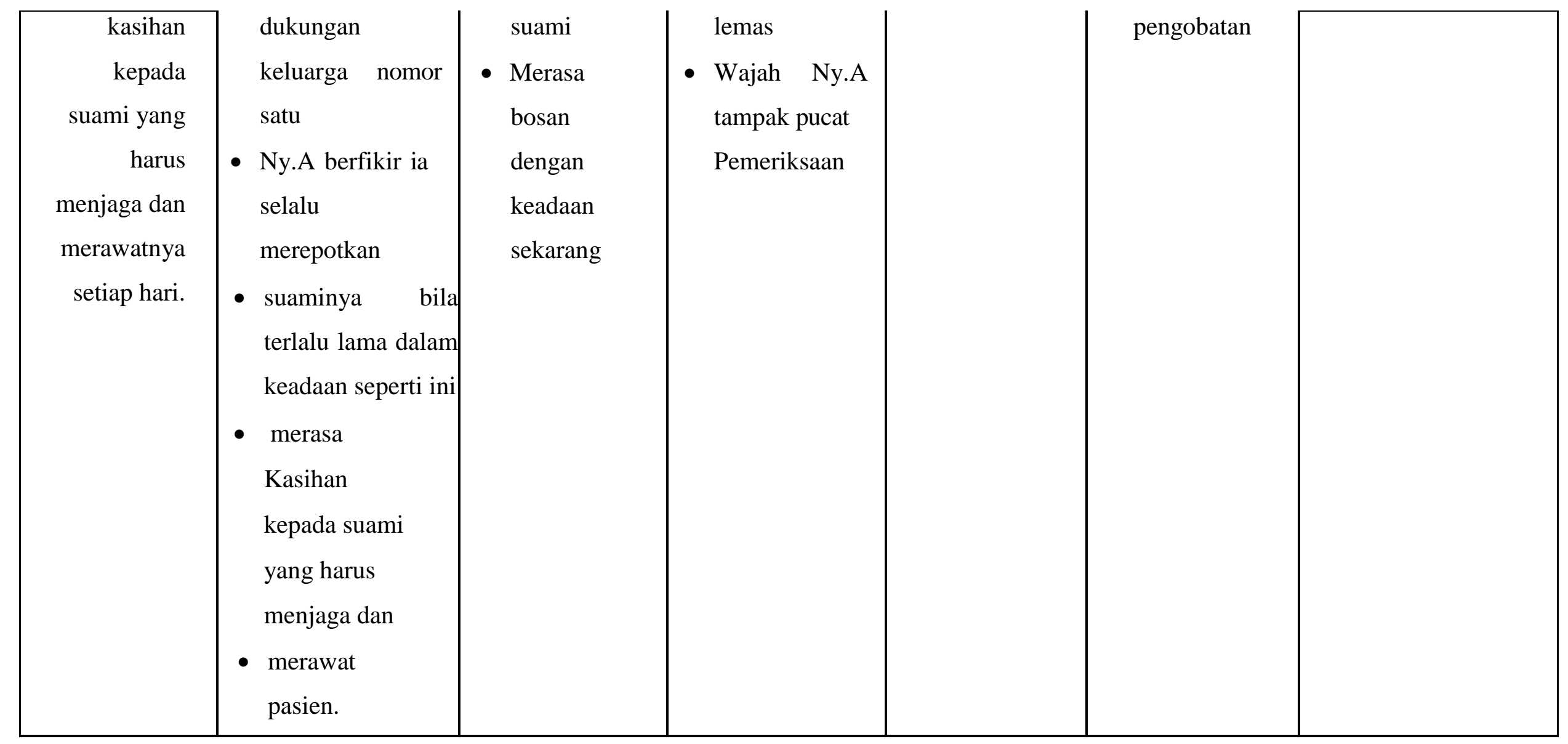




\subsubsection{Sumber Koping}

\begin{tabular}{|c|c|c|c|c|c|}
\hline $\begin{array}{c}\text { DIAGNOSA } \\
\text { KEPERAWATAN }\end{array}$ & PERSONAL ABILITY & $\begin{array}{c}\text { SOSIAL } \\
\text { SUPPORT }\end{array}$ & $\begin{array}{c}\text { MATERIA } \\
\text { L } \\
\text { ASSETS }\end{array}$ & $\begin{array}{l}\text { POSITIE } \\
\text { BELIEFS }\end{array}$ & TERAPI \\
\hline Ansietas & $\begin{array}{l}\text { - Ny.A mampu } \\
\text { mengungkapkan } \\
\text { perasaan cemas } \\
\text { - Ny.A mengatakan bila } \\
\text { cemasnya memuncak } \\
\text { maka ia akan } \\
\text { mengambil air wudhu } \\
\text { dan sholat }\end{array}$ & $\begin{array}{l}\text { - } \text { Ny.A mendapat } \\
\text { dukungan dari } \\
\text { keluarga untuk } \\
\text { kesembuhannya } \\
\text { terutama dari } \\
\text { suaminya } \\
\text { - Suami dan adik } \\
\text { Ny.A bergantian } \\
\text { merawat pasien }\end{array}$ & $\begin{array}{l}\text { - Sosial ekonomi } \\
\text { Ny. A menengah } \\
\text { Pengobatan } \\
\text { ditanggung BPJS } \\
\text { - Jarak rumah Ny.S } \\
\text { dengan tempat } \\
\text { pelayanan } \\
\text { kesehatan lebih } \\
\text { kurang } 500 \text { meter }\end{array}$ & $\begin{array}{l}\text { - Ny.Spercaya bahwa } \\
\text { petugas kesehatan } \\
\text { akan membantunya } \\
\text { - Ny.Aberharap cepat } \\
\text { sembuh agar tidak } \\
\text { merepotkan } \\
\text { Suaminya }\end{array}$ & $\begin{array}{l}\text { Terapi spesialis: } \\
\text { - } \text { Relaksasi } \\
\text { progresif } \\
\text { - } \text { Psikoedukasi } \\
\text { keluarga } \\
\text { - Behavior } \\
\text { therapy } \\
\text { - Psikoedukasi } \\
\text { keluarga }\end{array}$ \\
\hline
\end{tabular}




\begin{tabular}{|c|c|c|}
\hline $\begin{array}{ll}\text { Penampilan peran } \\
\text { tidak efektif }\end{array}$ & 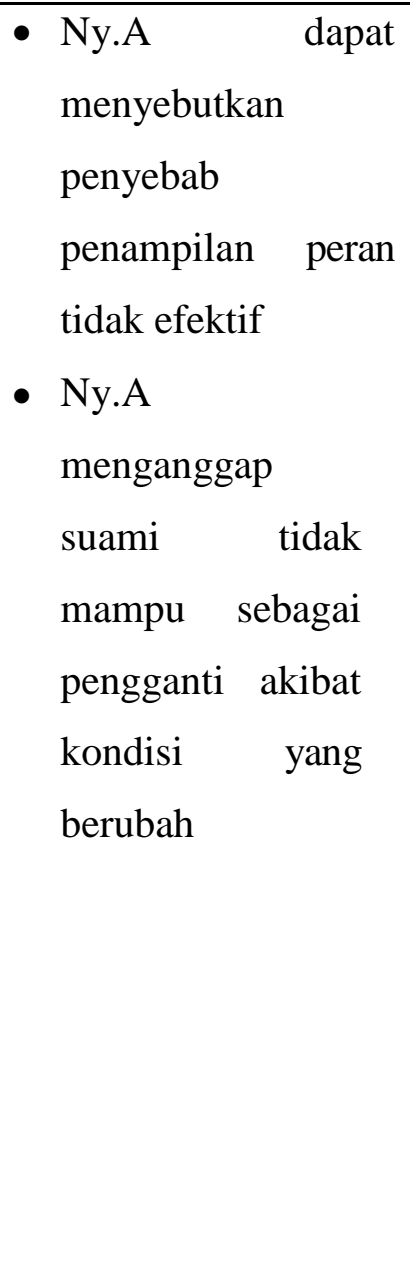 & $\begin{array}{l}\text { - Ny.A selalu } \\
\text { berdoa untuk } \\
\text { kesembuhan } \\
\text { penyakitnya } \\
\text { - Ny.A yakin, bila ia } \\
\text { mengikuti petunjuk } \\
\text { dan saran dari } \\
\text { petugas kesehatan } \\
\text { maka ia akan cepat } \\
\text { sembuh } \\
\text { Ny.A yakin suami } \\
\text { dan keluarga } \\
\text { mendukung supaya } \\
\text { lekas sembuh } \\
\text { - Ny.A percaya bahwa } \\
\text { petugas kesehatan } \\
\text { akan membantunya } \\
\text { - Ny.A berharap }\end{array}$ \\
\hline
\end{tabular}




\begin{tabular}{|l|l|l|l|l|l|}
\hline & & & & & $\begin{array}{l}\text { cepat sembuh agar } \\
\text { tidak merepotkan } \\
\text { suaminya }\end{array}$ \\
& & & & & \\
\end{tabular}




\begin{tabular}{|c|c|c|c|c|c|}
\hline Kurang pengetahuan & $\begin{array}{l}\text { - Ny.A mampu mengenal } \\
\text { dan menilai } \\
\text { Komplikasi dari } \\
\text { penyakitnya } \\
\text { - Ny.A mampu } \\
\text { melatih cara hidup } \\
\text { sehat }\end{array}$ & $\begin{array}{l}\text { - Ny.A mendapat } \\
\text { dukungan dari } \\
\text { keluarga untuk } \\
\text { kesembuhannya } \\
\text { terutama dari } \\
\text { suaminya } \\
\text { - Suami dan } \\
\text { keluarga Ny.A } \\
\text { bergantian } \\
\text { menjaga dan } \\
\text { mengunjungi } \\
\text { pasien } \\
\text { Tetangga Ny.A } \\
\text { dan teman di } \\
\text { tempat kerja } \\
\text { juga banyak } \\
\text { yang } \\
\text { mengunjungi }\end{array}$ & $\begin{array}{l}\text { - Sosial ekonomi } \\
\text { Ny.A menengah } \\
\text { - Ny.A tinggal di } \\
\text { rumah sendiri, } \\
\text { rumah } \\
\text { permanen } \\
\text { - Sarana dan } \\
\text { prasarana } \\
\text { tersedia } \\
\text { - Biaya } \\
\text { pengobatan } \\
\text { ditanggung oleh } \\
\text { asuransi BPJS } \\
\text { Jarak rumah Ny } \\
\text { A.Sdengan } \\
\text { tempat } \\
\text { pelayanan } \\
\text { kesehatan }\end{array}$ & $\begin{array}{l}\text { - Ny.A percaya bahwa } \\
\text { petugas kesehatan } \\
\text { akan membantunya } \\
\text { - Ny.A berharap } \\
\text { cepat sembuh agar } \\
\text { tidak merepotkan } \\
\text { suaminya } \\
\text { - Ny.A selalu } \\
\text { berdoa untuk } \\
\text { kesembuhan } \\
\text { penyakitnya } \\
\text { Ny.A yakin, bila ia } \\
\text { mengikuti } \\
\text { petunjuk dan saran } \\
\text { dari petugas } \\
\text { kesehatan maka ia } \\
\text { akan cepat sembuh } \\
\text { Ny.A yakin suami }\end{array}$ & \begin{tabular}{|l} 
Terapi generalis: \\
- SP \\
kurang \\
pengetahuan \\
Terapi spesialis: \\
Terapi suportif, \\
FPE
\end{tabular} \\
\hline
\end{tabular}




\begin{tabular}{|l|l|l|lr|l|l|}
\hline & pasien & (RSMM) lebih & dan keluarga & \\
kurang & 500 & $\begin{array}{l}\text { mendukung } \\
\text { supaya lekas } \\
\text { sembuh }\end{array}$ & \\
& & & & & \\
& & & & & & \\
\end{tabular}




\subsubsection{Mekanisme Koping}

\section{HAL YANG \\ DILAKUKAN}

ANALISA

- Ny.A mengatakan bila ada masalah, maka ia akan membicarakan dengan suami dan keluarga untuk mencari jalan keluarnya

- Bila sakit Ny.A berobat ke pelayanan kesehatan

- Ny.A taat menjalankan ibadah sesuai dengan keyakinannya

- Ny.A selalu berdoa kepada Allah SWT untuk kesembuhannya

- Konstruktif:

$\checkmark$ Ny.A mengatakan bila ada masalah, maka ia akan membicarakan dengan suami dan keluarga untuk mencari jalan keluarnya

$\checkmark$ Bila sakit Ny.A berobat ke pelayanan kesehatan

$\checkmark$ Ny.A taat menjalankan ibadah sesuai dengan keyakinannya

$\checkmark$ Ny.A selalu berdoa kepada Allah SWT untuk kesembuhannya.

- Destruktif : - 


\subsubsection{Status Mental}

\begin{tabular}{|l|l|}
\hline 1. Penampilan & Bersih, rapi, tidak tercium bau, Ny.A tampak lemas \\
\hline 2. Pembicaraan & Susah berbicara akibat dari kelumpuhan sebelah dari anggota tubuh (afasia ) \\
\hline 3. Aktivitas motoric & Tubuh sulit digerakkan \\
\hline 4. Interaksi selama wawancara & Cukup kooperatif, meskipun afasia \\
\hline 5. Alam perasaan & Sedih, merasa cemas ,takut dan bingung mengenai kondisi penyakit, suami dan anak-anaknya \\
\hline 6. Afek & Datar \\
\hline 7. Persepsi & Ny.A mengalami gangguan dalam proses sensori-persepsi \\
\hline 8. Isi piker & Mengalami masalah karena sebagian memori terlupakan \\
\hline 9. Proses piker & masalah karena sebagian memori terlupakan \\
\hline 10. Tingkat kesadaran & Ny.Adapat menyebutkan kembali nama suami \\
\hline 11. Daya ingat & Ny.A tidak dapat mengingat beberapa kejadian dalam hidupnya \\
\hline 12. Kemampuan berhitung & Kemampuan berhitung cukup baik \\
\hline 13. Penilaian & Ny.A belum mampu menyebutkan bagaimana caranya agar Ny.Slekas sembuh \\
\hline 14. Daya tilik diri & $\begin{array}{l}\text { Ny.Amenyadari bahwa saat ini ia sdang sakit, Ny.A hanya bisa berdoa supaya lekas sembuh agar } \\
\text { tidak terus merepotkan suaminya. Ny.A menyadari ia memiliki suami, anak-anak dan keluarga } \\
\text { yang menyayanginya dan mendukung kesembuhannya }\end{array}$ \\
\hline
\end{tabular}


Kesimpulan : Mental Status Examination (MSE) tidak ada masalah gangguan jiwa, gangguan Ny.A lebih kepada Gangguan

Mental Emosional (GME/Psikososial)

\subsection{Diagnosa Dan Terapi}

\begin{tabular}{|l|l|}
\hline DIAGNOSA KEPERAWATAN DAN TERAPI KEPERAWATAN & DIAGNOSA MEDIS \\
\hline 1. Ansietas & Diabetes Melitus \\
Sp1: mendiskusikan penyebab,terjadinya prosesterjadi, tanda gejala, akibat & \\
Sp2 :melatih teknik releksasi fisik & \\
Sp3:melatih mengatasi ansietas dengan distraksi dan hipnotis lima & \\
Sp4 : melatih mengatasi ansietas memalui kegiatan spritual & \\
Terapi Spesialis: TS, PMR, Logo ACT & \\
2. Penampilan peran tidak efektif & \\
Terapi perilaku & \\
3. & Kurang pengetahuan \\
Terapi suportif, FPE & \\
\hline
\end{tabular}




\subsection{Implementasi Tindakan Kperawatan Dan Evaluasi}

\begin{tabular}{|c|c|}
\hline IMPLEMENTASI TINDAKAN KEPERAWATAN & EVALUASI \\
\hline $\begin{array}{l}\text { Tanggal : } 06 \text { Oktober } 2021 \\
\text { Jam : } 10.00 \text { wib } \\
\text { e. Kaji tanda dan gejala ansietas dan kemampuan klien mengurangi } \\
\text { kecemasan } \\
\text { f. Jelaskan tanda dan gejala, penyebab dan akibat dari kecemasan } \\
\text { g. Latihan cara mengatasi kecemasan : } \\
\text { 4) Teknik relaksasi napas dalam } \\
\text { 5) Distraksi : bercakap-cakap hal positif } \\
\text { 6) Hipnotis } 5 \text { jari fokus padahal-hal yang positif } \\
\text { h. Bantu klien melakukan latihan sesuai dengan jadwal kegiatan. }\end{array}$ & 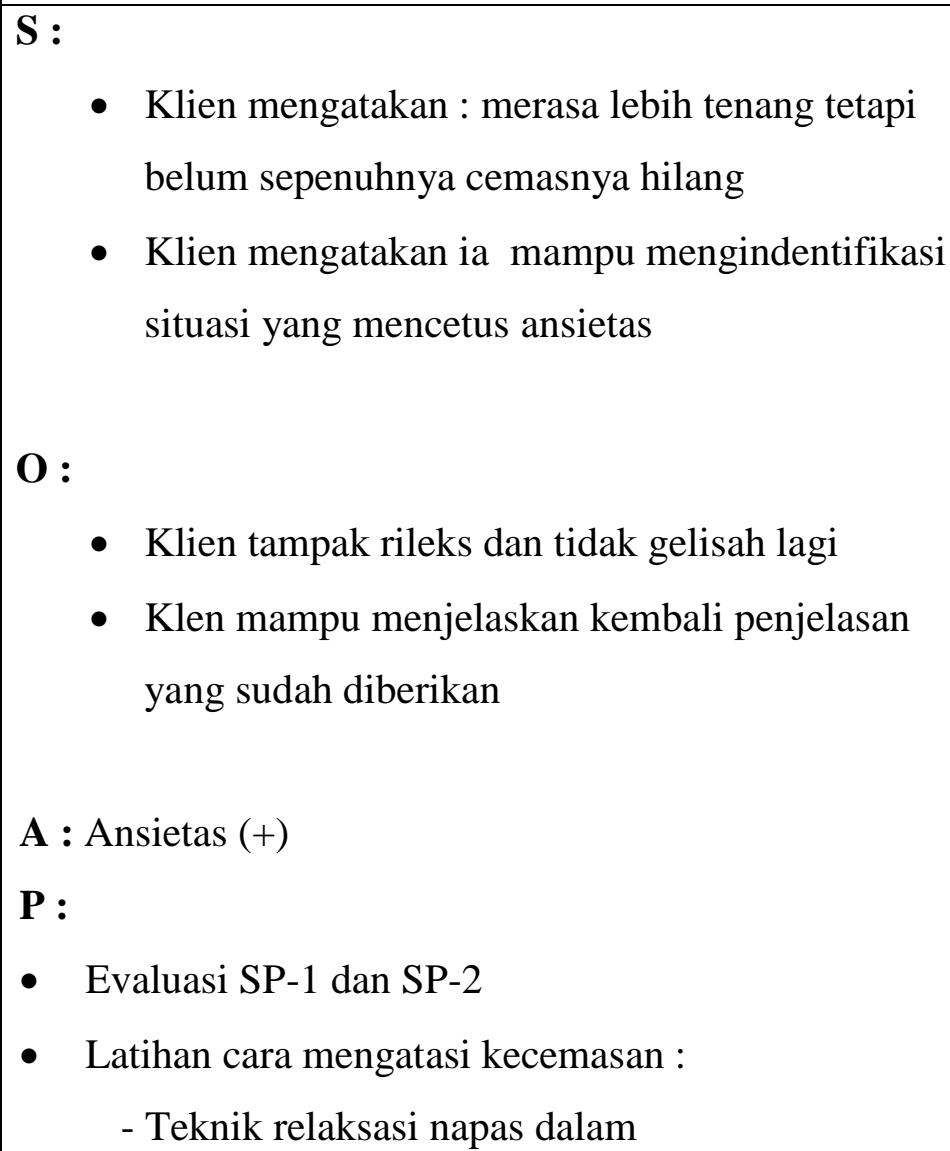 \\
\hline
\end{tabular}




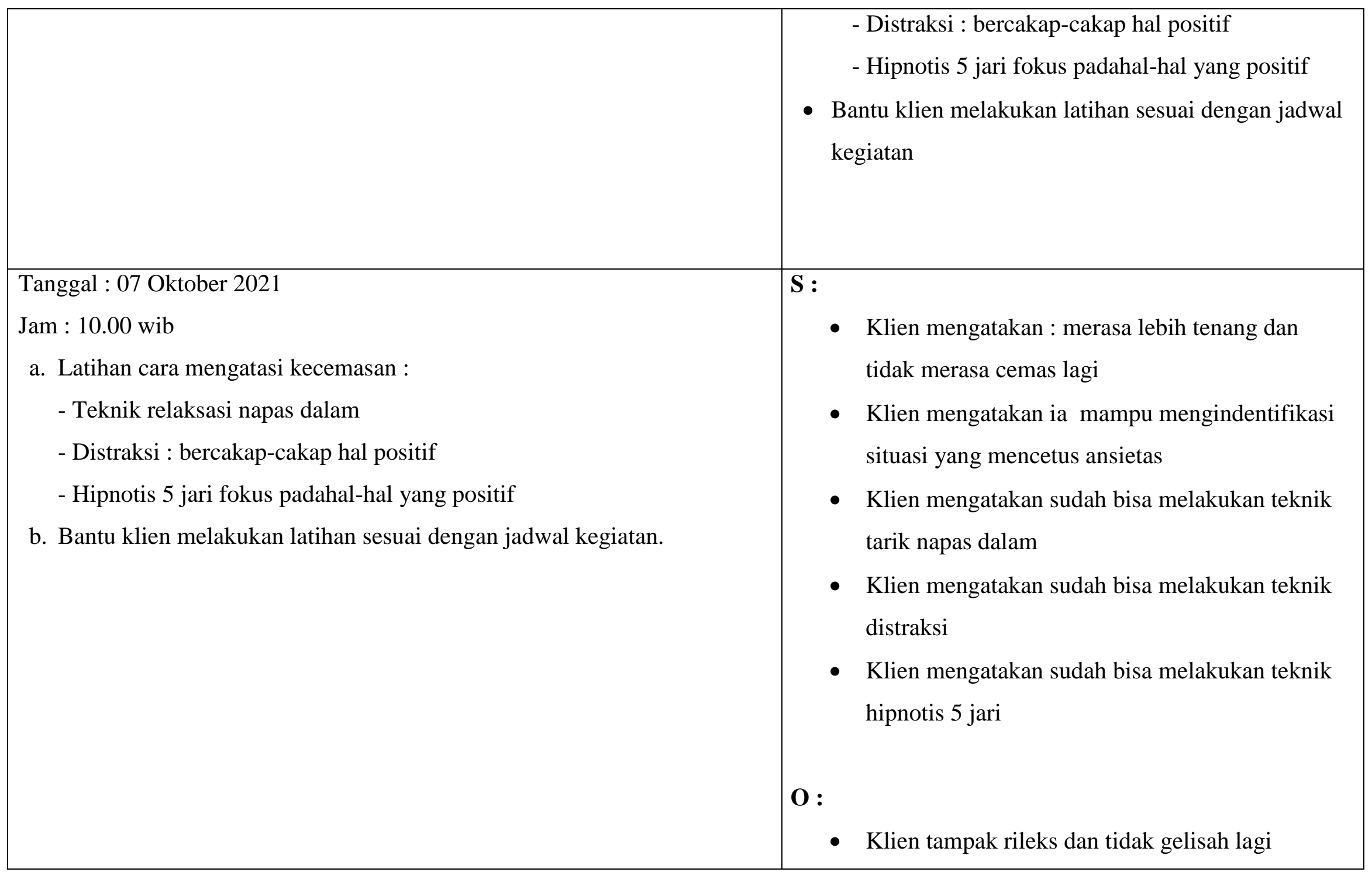




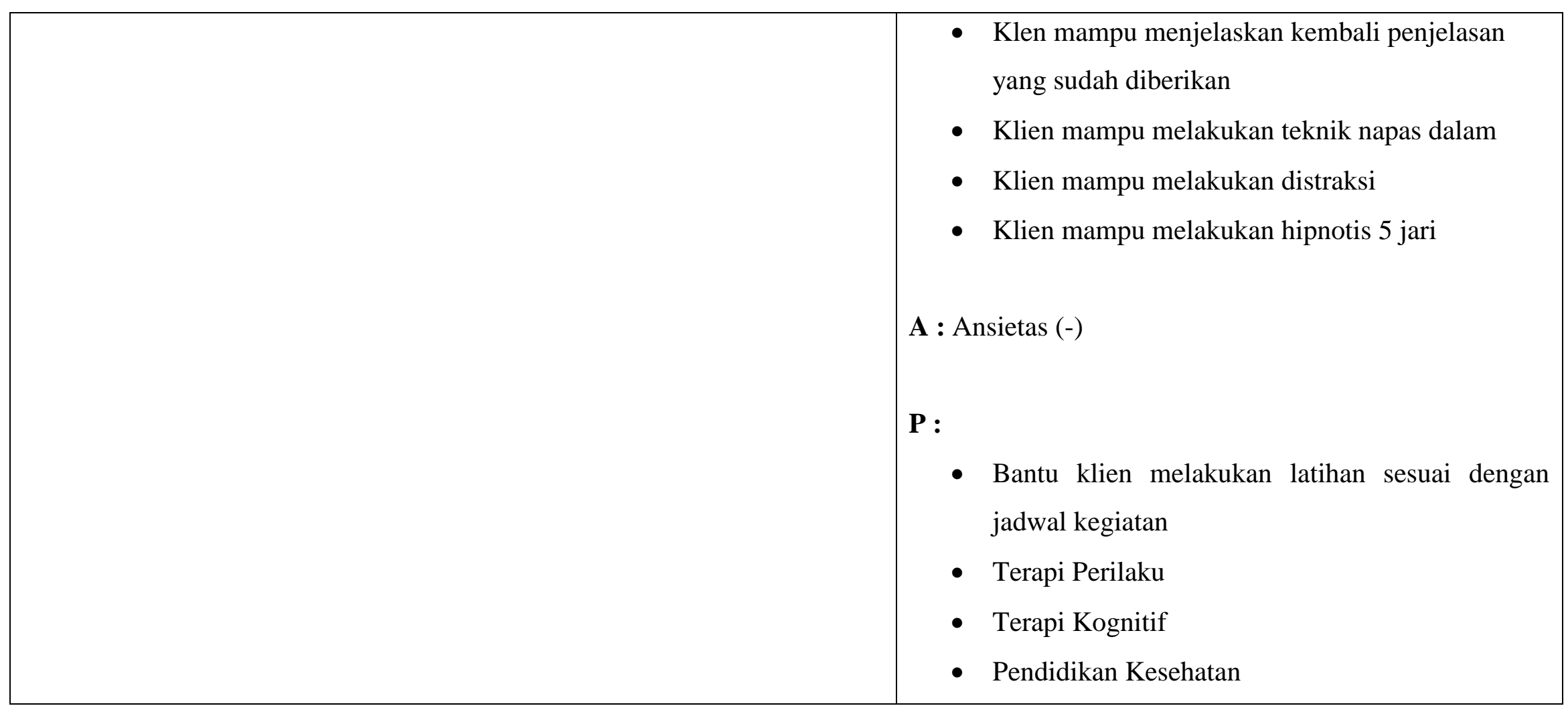




\section{BAB 4 \\ PEMBAHASAN}

Pada pembahasan ini penulis membahas tentang kesenjangan yang ditemukan antara teori dengan kasus yang penulis buat, pada pembahasan ini penulis menganalisa tentang hambatan yang ditemukan pada saat penulis melakukan asuhan keperawatan pada klien.

Pada tahap pengkajian ditemukan adanya beberapa kesenjangan diantaranya respon perilaku. Pada respon perilaku menurut teori tanda gejalanya adalah rasa terbakar di jantung, sering kencing dan kulit terasa panas, sedangkan pada kasus adalah klien tidak menunjukkan respon perlaku seperti pada teori. Hal ini disebabkan karena kecemasan yang dialami klien masih tahap sedang.

Pada tahap diagnosa dan perencanaan tidak ditemukan kesenjangan antara teori dan kasus dimana diagnosa yang diangkat adalah kecemasan, penampilan peran tidak efektif dan kurang pengetahuan sama halnya dengan intervensi, rencana asuhan keperawatan pada Ny. A dimulai setelah data terkumpul yang didapat dari hasil pengkajian. Tindakan yang diberikan pun yaitu terapi dan pendidikan kesehatan. Pembahasan pada implementasi penulis melaksanakan tindakan keperawatan sesuai dengan rencana yang sudah ditetapkan. Sebelumnya penulis melakukan kontrak waktu kepada pasien untuk melakukan implementasi, selama tahap implementasi tidak ada hambatan dan klien kooperatif dalam mengikuti terapinya.

Pada tahap evaluasi penulis hanya dapat melaksanakan diagnosa keperawatan yang pertama saja. Pada evaluasi yang diharapkan adalah :

a. Membina hubungan saling percaya

b. Mengenali dan mengekspresikan emosinya

c. Mampu mengenal ansietas

d. Mampu mengatasi ansietas melalui teknik releksasi

e. Mampu mengatasi ansietas dengan distraksi

f. Mampu mengatasi ansietas melalui hipnotis lima jari

g. Mampu mengatasi ansietas melalui kegiatan spritual 


\section{BAB 5}

\section{PENUTUP}

\subsection{Kesimpulan}

Berdasarkan konsep asuhan keperawatan yang telah disusun dan dilaksanakan kepada Ny.A dimiliki dari pengkajian, rumusan masalah, perencanaan, pelaksanaan hingga evaluasi didapat hasil bahwa Ny.A dengan keluhan utama cemas akan Penyakit diabetes melitus sehingga tidak mampu melakukan aktivitas seperti biasanya Data objektif yaitu klien tampak Badan lemas,kesemutan, gatal, gemetaran pusing luka yang lama sembuh, Kadar glukosa darah tinggi Dari masalah masalah diatas maka diperoleh prioritas masalah yang diangkat adalah tentang kebutuhan rasa aman nyaman yang berfokus pada cemas. Kemudian diberikan intervensi secara konsep yaitu terapi teknik relaksasi napas dalam, terapi distraksi, hipnotis lima jari dan pendidikan kesehatan. Dari hasil implementasi ada beberapa intervensi yang berhasil teratasi seperti klien mengatakan sudah lebih tenang dan cemas nya sedikit berkurang dan mampu mengenali gejala, tanda, penyebab dan akibat dari kecemasan. Sedangkan klien masih bingung dalam melakukan terapi hipnotis lima jari maka intervensi dilanjutkan.

\subsection{Saran}

Diharapkan bagi perawat selalu berkoordinasi dengan tenaga kesehatan lainnya dalam memberikan asuhan keperawatan agar lebih maksimal terkusus pada klien dengan kecemasan pada pasien diabetes melitus. 


\section{DAFTAR PUSTAKA}

1. Yulia, A. (2020). Hubungan Tingkat Pengetahuan Tentang Senam Kaki Dengan Tindakan Pencegahan Komplikasi Kaki Pada Pasien Diabetes Mellitus. Menara Ilmu, 14(1).

2. Maruhashi, T., \& Higashi, Y. (2021). Pathophysiological Association between Diabetes Mellitus and Endothelial Dysfunction. Antioxidants, 10(8), 1306.

3. Regina, C. C., Mu'ti, A., \& Fitriany, E. (2021). Systematic Review Tentang Pengaruh Obesitas Terhadap Kejadian Komplikasi Diabetes Melitus Tipe Dua. Verdure: Health Science Journal, 3(1), 8-17.

4. Riskesdas .(2018). Kementrian Kesehatan Republik Indonesia, Riset Kesehatan Dasar 2018

5. Zaini, M. (2019). Asuhan keperawatan Jiwa Masalah Psikososial Di Pelayanan Klinis dan Komunitas. Deepublish : Yogyakarta.

6. Oxyandi, M., Fitrayani, C., \& Nurhayati, N. (2018). Ubungan Umur, Komunikasi Terapeutik Perawat Dan Dukungan Keluarga Terhadap Tingkat Kecemasan Pasien Pre Operatif Di Ruang Marwah Rumah Sakit Islam Siti Khadijah Palembang Tahun 2018. Jurnal Kesehatan Lentera'Aisyiyah, 1(1), $1-12$.

7. Hulu, E. K., \& Pardede, J. A. (2016). Dukungan Keluarga Dengan Tingkat Kecemasan Pasien Pre Operatif Di Rumah Sakit Sari Mutiara Medan. Jurnal Keperawatan, 2(1).

8. Pardede, J. A., \& Simangunsong, M. M. (2020). Family Support With The Level of Preschool Children Anxiety in the Intravenous Installation. Jurnal Keperawatan Jiwa (JKJ): Persatuan Perawat Nasional Indonesia, 8(3), 223234. https://doi.org/10.26714/jkj.8.3.2020.223-234

9. Pardede, J. A. (2020). Standar Asuhan Keperawatan Jiwa Dengan Masalah Kecemasan.

10. Pardede, J., Simanjuntak, G. V., \& Manalu, N. (2020). Effectiveness of deep breath relaxation and lavender aromatherapy against preoperative patient anxiety. Diversity and Equality in Health and Care, 17(4), 168-173.

11. Nevid, J. S., \& Gordon, A. J. (2018). Integrated learning systems: Is there a learning benefit?. Teaching of Psychology, 45(4), 340-345. 
12. Nanda, S. N. (2018). Asuhan Kebidanan Continuity Of Care Pada Ny. S Dengan Keputihan Di PMB Hj. Farida hajri s. St surabaya (Doctoral dissertation, Universitas Muhammadiyah Surabaya).

13. Stuart. Gail. W, Keliat. Budi. Anna,\& Pasaribu. Jesika.(2016). Keperawatan kesehal11tan jiwa : Indonesia : Elsever.

14. Febrianti, D., Hamid, A. Y. S., \& Wardani, I. Y. (2015). Gambaran Asuhan Keperawatan Pada Klien Hipertensi Dengan Ansietas Menggunakan Pendekatan Uncertainty in Illness Dan Comfort Theory. Jurnal Ilmu Kesehatan, 7(2), 113-118.

15. Sari, H. (2015). Penerapan Terapi Kelompok Suportif Pada Ibu Hamil Dengan Ansietas Melalui Pendekatan Teori Mercer Di Kelurahan Balumbang Jaya, Bogor Barat. Idea Nursing Journal, 2(2), 153-161.

16. Pratiwi, S. R., Widianti, E., \& Solehati, T. (2017). Gambaran faktor-faktor yang berhubungan dengan kecemasan pasien kanker payudara dalam menjalani kemoterapi. Jurnal Pendidikan Keperawatan Indonesia, 3(2), 167174.

17. Utami, T. W., Astuti, Y. S., \& Livana, P. H. (2017). Hubungan Kecemasan Dengan Depresi Pada Anak Sekolah Dasar. Jurnal Keperawatan, 9(1), 1-5.

18. Naja, G., Halasz, A., Thiboutot, S., Ampleman, G., \& Hawari, J. (2008). Degradation of hexahydro-1, 3, 5-trinitro-1, 3, 5-triazine (RDX) using zerovalent iron nanoparticles. Environmental science \& technology, 42(12), 4364-4370.

19. Rahayu, N. W. (2016). Studi Kasus pada Klien Ansietas dengan Pendekatan Teori Adaptasi Stuart.

20. Pardede, J. A., Simanjuntak, G. V., \& Waruwu, J. F. A. P. (2020). Penurunan Tingkat Kecemasan Pasien HIV/AIDS melalui Terapi Hipnotis Lima Jari. Coping: Community of Publishing in Nursing, 8, 85-90.

21. Pardede, J. A., Keliat, B. A., Damanik, R. K., \& Gulo, A. R. B. (2020). Optimalization of Coping Nurses to Overcoming Anxiety in the Pandemic of Covid-19 in Era New Normal. Jurnal Peduli Masyarakat, 2(3), 105-112. 